See discussions, stats, and author profiles for this publication at: https://www.researchgate.net/publication/318164775

Ten Years After: Revisiting the Determinants of the Adoption of Municipal Corporations for Local Service Delivery

Article in Local Government Studies · July 2017

DOI: $10.1080 / 03003930.2017 .1356723$

\section{CITATIONS}

31

1 author:

António Tavares

University of Minho

68 PUBLICATIONS 1,027 CITATIONS

SEE PROFILE

Some of the authors of this publication are also working on these related projects:

Project Managerial Influence on Sustainable Development Policy View project

Project Intermunicipal Cooperation in Europe View project 


\title{
Ten Years After: Revisiting the Determinants of the Adoption of Municipal Corporations for Local Service Delivery
}

\begin{abstract}
Research on the use of municipal corporations to deliver local and regional public services has evolved significantly in the past decade. Most of this work addresses the performance of this service delivery mode vis-à-vis local bureaucracies. However, much less is known about the drivers for the adoption of municipal corporations in the first place. This article reviews the main determinants of adoption - service characteristics, institutional and regulatory settings, political constraints, and financial conditions - and highlights the need for comparative research across countries.
\end{abstract}

Keywords: municipal corporations, public authorities, corporatization, service delivery

\section{Introduction}

Ten years ago, Tavares and Camões (2007) published an empirical study about the determinants of the adoption of municipal corporations in Portugal. At the time, Portugal had witnessed a significant expansion in the number of municipal corporations during the previous decade, so it made sense to question the factors leading to the preference for this specific arrangement for the delivery of local public services. The authors investigated the use of municipal corporations in seven service areas: water supply and waste management, recreation and sports, economic development, culture and science, parks and maintenance, transportation, and affordable housing. Findings pointed to service characteristics, institutional and regulatory settings, political constraints, and financial conditions as decisive factors influencing the creation of municipal corporations in Portugal.

Recent work by Voorn et al. (2017) reviews the literature on municipal corporations from the perspective of their efficiency and effectiveness vis-à-vis the local bureaucracy. In contrast, the literature exploring the determinants of adoption of the municipal corporation model is far more limited. This article takes municipal corporations as the dependent variable and examines the factors influencing their creation by reviewing the literature published in the last decade on this topic. ${ }^{1}$ First, I present a working definition of municipal corporations. Next, I focus on the findings present in the literature related to the four sets of factors identified by Tavares and Camões (2007). This update closes with a brief set of conclusions and identifies some gaps warranting future research.

\section{Municipal Corporations: A Definition}

The typical municipal bureau operates under administrative law, is tax-financed and subject to competitive budget allocations, and is entirely dependent upon the

\footnotetext{
${ }^{1}$ First and foremost, I focus on the choice to establish municipal corporations with $100 \%$ of shares owned by a single municipality, since the factors contributing to the choice of mixed firms has been extensively addressed in the overview by Bel, Brown and Warner (2014).
} 
preferences of local elected officials (Tavares and Camões 2010). In contrast, municipal corporations can be described as stand-alone organizations which "rely on revenues derived from user fees, are governed by an appointed executive board, and have independent corporate status" (Tavares and Camões 2007: 535). Typically, they are single-purpose organizations, operate under private law or a mix of both public and private law, and have high flexibility to enter cooperative agreements with either public or private partners (Voorn et al. 2017).

Compared to local bureaucracies, municipal corporations are responsible for better performance in terms of efficiency and effectiveness, making them appealing to private investors. As some become highly profitable and operate in sectors without competitors, they tend to attract private capital and are often converted into mixed firms (Lidström 2017). Municipal corporations lack direct democratic legitimacy, since their leaders are not elected (Lidström 2017), but public accountability is still partially secured through the appointment of the executive board by local government officials (Leavitt and Morris 2004).

\section{Empirical Research on Municipal Corporations: A Tentative Organization}

The use of municipal corporations across different countries is quite uneven. In some countries, local service delivery relies heavily on this arrangement. This is the case of Italy (Citroni et al. 2013; Garrone et al. 2013), Portugal (Tavares and Camões 2010; Da Cruz and Marques 2011), Spain (Bel and Fageda 2010; Zafra-Gómez et al. 2013), Norway (Sørensen 2007), Germany (Grossi and Reichard 2008; Kuhlmann 2008) and The Netherlands (Gradus et al. 2014). In the United States, they operate under different names, such as municipal enterprises (Rubin 1988; Stumm 1997) or public authorities (Bourdeaux 2004; Savitch and Adhikari 2017). This section reviews the literature on the determinants of municipal corporations divided into four groups: service characteristics, institutional and regulatory settings, political constraints, and financial conditions.

\section{Service characteristics}

Corporatization does not affect the whole range of services provided by local governments in a similar way. It is possible to detect patterns of adoption across service sectors. Potential capture of economies of scale and scope, the ability to calculate and apply unit-pricing to users, and services that can be measured in a more objective manner are more likely to be delegated to municipal corporations (Tavares and Camões 2010). Tavares and Camões (2007) found that the adoption of municipal corporations was more frequent in water supply and waste management, recreation and sports, economic development, culture and science, parks and maintenance, and transportation. High human asset specificity was found to be a deterrent of the transfer of health, education and social welfare services from local bureaucracies to municipal corporations. These politically-sensitive services are less likely to be transferred, because the loss of political control would endanger control over the quality of the service and prevent credit-claiming by local officials. In contrast, high technical asset specificity seems associated with more use of the municipal corporation model as an alternative to contracting out (Rodrigues et al. 2012; Wassenaar et al. 2013). 
Kuhlmann (2008) describes how corporatization of local public services has particularly affected the public utility sector in Germany (electricity, gas, water supply/sewerage, waste disposal, public transportation). Citroni et al. (2013) provide a list of 744 corporations directly owned by municipalities in Italy. Like in the German case, water and sanitation services, transportation, and waste collection and disposal services are more frequently attributed to municipal corporations than services displaying high human asset specificity. Later, the same authors present a sample of 1,335 municipal private law corporations in six regions and identify "water and sanitation services, waste management, and especially in local transports and multi-utilities (both "pure" multiutilities and corporations combining water or waste management with energy provision)" as the service areas most likely to opt for municipal corporations primarily controlled by public institutions. Mixed ownership is more prevalent in telecommunications and gas and energy (Citroni et al. 2015: 80).

The focus of the articles published about the topic also seems to support this claim. In their meta-analysis of studies about municipal corporations, Voorn et al. (2017) report that this arrangement is more frequently studied in the service areas of waste collection (14 articles), transportation (9), water management (8), and urban services/health services (2).

As the cases of Portugal and Italy clearly indicate, municipal corporations are also created to provide services in other functional areas, but their suitability is often less evident. Recently, the Portuguese national government was successfully lobbied to change existing sunset-type legislation in order to exempt municipal corporations operating in the area of cultural infrastructures from mandatory closing due to financial criteria. This was specifically done to prevent the municipal corporation running the $100-$ year-old Theatro Circo in the city of Braga from closing. This exception was later extended to corporations in the areas of education and social welfare. This anecdotal evidence points to the inappropriateness of trying to fit the municipal corporation model for the "wrong" services.

\section{Institutional and Regulatory Settings}

What institutional conditions are more likely to favour the creation of municipal corporations? Corporatization is often regarded as an alternative to private ownership or concessions to private firms (Leavitt and Morris 2004). Subject to private law (or, depending on the particular country, a mix of public and private law), municipal corporations possess increased flexibility and autonomy in public procurement, in hiring and firing (through private labour law rather than civil service systems), and in budgeting and financial management rules (circumventing inefficient spending and carrying over regulations). This is regarded as one of the major drivers of this trend towards corporatization in Germany (Grossi and Reichard 2008) and Portugal (Tavares and Camões 2010).

Kuhlmann (2008) underscores the retreat of local governments to an 'enabling function' as one of the possible causes for the expansion of the number of corporations, which 
originates increased institutional fragmentation of the local landscape into singlepurpose organizations. Regional fragmentation has also been associated with the expansion of public authorities in the United States (U.S.). Savitch and Adhikari (2017) argue that public authorities have been employed to integrate fragmented metropolises and respond to selective regional pressures. In contrast with the German case described by Kuhlmann (2008), public authorities in the U.S. are a solution to rather than a cause of regional fragmentation.

The regional organization of local governments - more consolidated or more fragmented - has also been associated with an increase in the number of corporations, particularly mixed firms. Bel and Fageda (2010) find that both larger cities acting alone and small cities engaged in inter-municipal cooperation are more likely to opt for corporatization. Mixed corporations are an attractive model, since both larger cities and inter-municipal cooperation guarantee bigger size and, hence, better bargaining power in regional and national markets. Grossi and Reichard (2008) report that, on average, local governments in Germany's largest cities have an average of 90 municipal corporations, in contrast to the national average of 20 municipal corporations per local government. A similar trend can be witnessed in Italy, with cities above 50,000 inhabitants owning about half of total number of municipal corporations in the country. Łukomska and Szmigiel-Rawska (2017) also find that municipal corporations are only present in Poland's largest cities.

In sum, corporatization has been motivated by the advantages afforded by rule flexibility to address industrial scale type of operations without completely relinquishing control over the socio-political orientation in service delivery. At the same time, it tends to be more common in larger cities to capture economies of scale and in more fragmented metropolises as a pragmatic tool to achieve increased regional integration.

\section{Political Constraints}

As discussed in the previous section, municipal corporations have the potential to realize productive efficiency gains as a result of more flexible personnel, public procurement, and financial management rules, but these gains are possibly countered by some loss of political control (Tavares and Camões 2007). Whether this loss of political control is regarded by local elected officials as a missed opportunity for credit-claiming or as a blame avoidance strategy is likely to be both service and context-specific.

Earlier research by Bourdeaux (2004) investigated the creation of public authorities for managing solid waste systems in the state of New York and found that elected officials experiencing higher political competitiveness were more likely to choose public authorities to manage the service. The author attributed this to either "ensuring political stability across election cycles or to avoid blame" in a politically-charged environment (2004: 454).

Tavares and Camões (2007) were able to show that the political setting where local governments operate is an important factor contributing to the creation of municipal corporations. For several service areas, highly fragmented municipalities (into sub- 
municipal governments) were more likely to delegate tasks to municipal corporations in order to avoid political conflict stemming from sub-municipal governments acting as interest groups. Da Cruz and Marques (2011) investigate a sample of municipal companies in Portugal and find excessive dependence on the city as a shareholder and the systematic inability to develop an independent vision for the companies. The authors speculate that this is likely due to political patronage involved in setting up the executive board of the municipal corporation.

Most research investigating the determinants of creation of municipal corporations suggests their choice as a middle-of-the-road strategy to capture economies of scale and scope while avoiding significant loss of political control associated with privatization of ownership or long-term concession contracts to private firms (Bognetti and Robotti 2007). Under pressure to improve productive efficiency of industrial-type services, Tavares and Camões (2010) found that left-leaning local governments were more likely to rely on municipal corporations as this is more consistent with their ideology than privatization of ownership or concession contracts supported by their right-leaning counterparts. In the case of larger municipalities opting to maintain service delivery under some political control, municipal corporations are likely to become the preferred governance arrangement, as they allow gains of scale, specialization, and autonomy not allowed by in-house municipal bureaus (Tavares and Camões 2010). Partial privatization through mixed firms also allows local governments to engage in service restructuring without the loss of control rights (Garrone et al 2013).

\section{Financial Conditions}

One of the major appeals of corporatization of local services is the potential for capturing scale economies and achieving productive efficiency. Local governments under fiscal stress are more likely to move to the municipal corporation model, as evidenced by local government choices in Germany, where municipalities either tried to "hide their liabilities by allocating them partly to their companies" or "corporatized their utilities (...) to raise new sources of income from their companies" (Gross and Reichard 2008: 607). This has also been presented as the primary motivation for the creation of inter-municipal corporations under shared ownership by local governments (Sørensen 2007; Citroni et al. 2013; Bel and Warner 2016).

The findings for Portugal are more mixed, indicating that the adoption of municipal corporations, starting in 1998, was largely "the politics of good times", since it took place in local governments showing higher financial independency from transfers from the national government (Tavares and Camões 2010). Nevertheless, the authors did find that municipalities with higher fiscal burdens were likely to have more municipal corporations. However, after the financial crisis of 2008 and the bailout of 2011, municipal corporations have been rolled back, primarily as a result of the adoption of new, more stringent legislation concerning both their adoption and persistence (sunsettype legislation).

For mixed firms, in contrast, market appeal is one of the major drivers for their growth in numbers. Some empirical works have focused on the conversion of municipal 
corporations with 100 percent of shares held by a single municipality to the mixed corporation format. Kuhlmann (2008) reports on a survey of the German Institute of Urban Studies according to which only about 30 percent of municipal energy corporations are entirely held by their parent government and 70 percent have private shareholders. This trend is even more evident in the largest cities in Germany, where local governments were minority shareholders in about 20 percent of the energy corporations (Kuhlmann 2008).

\section{Conclusion: Bridging the Gaps}

The adoption of the municipal corporation model is, to a certain extent, dependent on context-specific factors. Nevertheless, the scant literature allows us to identify some patterns in terms of preferred service-types, favourable institutional settings, major political constraints, and supporting financial conditions. This review indicates that the municipal corporation model is primarily used for the provision of utilities (solid waste collection and disposal, water supply, and transportation), not only because it fits the scale required by industrial-type services and operations, but also because it provides significant flexibility in managing personnel, public procurement, and budgeting and financial rules.

Municipal corporations operate "at-arm's-length" of their parent government and their CEOs are political nominees chosen based on the competence. In theory, the degree of autonomy of municipal corporations vis-à-vis their local government should be significant. In practice, however, this is clearly context-specific, as it can be witnessed by the works reviewed here. One finding which seems to hold across countries is that municipal corporations tend to be established by local governments experiencing some degree of fiscal stress, which is also consistent with the findings of the literature on the externalization of local public services.

The empirical literature reviewed here is primarily focused on the study of single country cases. Future studies should focus on extending the breadth of this research, in order to take advantage of the potential insights which could be drawn from comparative research involving multiple countries and varying institutional settings.

\section{References}

Bel, G., T. Brown and M. Warner. 2014. "Mixed and Hybrid Models of Public Servic Delivery." International Public Management Journal 17 (3): 297-307.

Bel, G., and X. Fageda. 2010. "Partial Privatization in Local Service Delivery: An Empirical Analysis of the Choice of Mixed Firms." Local Government Studies 36 (1): 129-149. doi:10.1080/03003930903435856.

Bel, G. and M. Warner. 2016. "Factors explaining inter-municipal cooperation in service delivery: A Meta-regression analysis." Journal of Economic Policy Reform 19 (2): 91-115.

Bognetti, G., and L. Robotti. 2007. "The Provision of Local Public Services through 
Mixed Enterprises: The Italian Case." Annals of Public and Cooperative Economics 78 (3): 415-437. doi:10.1111/apce.2007.78.issue-3.

Bourdeaux, C. 2004. "A Question of Genesis: An Analysis of the Determinants of Public Authorities." Journal of Public Administration Research and Theory 15 (3): 441-462.

Citroni, G., A. Lippi, and S. Profeti. 2013. "Remapping the State: Inter-municipal Cooperation Through Corporatisation and Public-Private Governance Structures." Local Government Studies 39 (2): 208-234.

Citroni, G., A. Lippi, and S. Profeti. 2015. "Representation through corporatisation: municipal corporations in Italy as arenas for local democracy." European Political Science Review 7 (1): 63-92.

Da Cruz, N. F., and R. C. Marques. 2011. "Viability of Municipal Companies in the Provision of Urban Infrastructure Services." Local Government Studies 37 (1): 93-110. doi:10.1080/03003930.2010.548551.

Garrone, P., L. Grilli, and X. Rousseau. 2013. "Management Discretion and Political Interference in Municipal Enterprises: Evidence from Italian Utilities." Local Government Studies 39 (4): 514-540.

Gradus, R. H., J. M. E. Dijkgraaf, and M. Wassenaar. 2014. "Understanding Mixed Forms of Refuse Collection, Privatization and Its Reverse in the Netherlands." International Public Management Journal 17 (3): 328-343. doi:10.1080/ 10967494.2014.935237.

Grossi, G., and C. Reichard. 2008. "Municipal Corporatization in Germany and Italy." Public Management Review 10 (5): 597-617.

Kuhlmann, S. 2008. "Reforming Local Public Services: Trends and Effects in Germany and France." Public Management Review 10 (5): 573-596.

Leavitt, W. and J. C. Morris. 2004. "In Search of Middle Ground: The Public Authority as an Alternative to Privatization." Public Works Management \& Policy 9 (2): 154-163.

Lidström, A. 2017. "Public Authorities and Intermunicipal Cooperation in a European Context." Urban Affairs Review 53 (2): 403-409.

Łukomska, J., and K. Szmigiel-Rawska. 2017. "Inter-Local Relations and Trans-Scaling through Finance in Poland." Journal of Economic Policy Reform (forthcoming).

Rodrigues, M., A. F. Tavares, J. Filipe Araújo. 2012. "Municipal Service Delivery: The Role of Transaction Costs in the Choice between Alternative Governance Mechanisms." Local Government Studies 38 (5): 615-638. doi:10.1080/03003930.2012.666211. 
Rubin, I. S. 1988. "Municipal Enterprises: Exploring Budgetary and Political Implications." Public Administration Review 48 (1): 542-550.

Savitch, H. V. and S. Adhikari. 2017. "Fragmented Regionalism: Why Metropolitan America Continues to Splinter." Urban Affairs Review 53 (2): 381-402.

Sørensen, R. J. 2007. "Does Dispersed Public Ownership Impair Efficiency? The Case of Refuse Collection in Norway." Public Administration 85 (4): 1045-1058. doi:10.1111/ j.1467-9299.2007.00681.x.

Stumm, T. J. 1997. "Comparing Alternative Service Delivery Modes: Municipal Enterprises Require Special Consideration." Journal of Urban Affairs 19 (3): 275-289.

Tavares, A. F., and P. J. Camões. 2007. "Local Service Delivery Choices in Portugal: A Political Transaction Costs Framework." Local Government Studies 33(4): 535-553. doi:10.1080/03003930701417544.

Tavares, A. F. and P. J. Camões. 2010. "New Forms of Local Governance: A Theoretical and Empirical Analysis of Municipal Corporations in Portugal." Public Management Review 12 (5): 587-608.

Voorn, B., M. L. van Genugten, and S. van Thiel. 2017. "The Efficiency and Effectiveness of Municipally Owned Corporations: A Systematic Review." Local Government Studies. Early view: http://dx.doi.org/10.1080/03003930.2017.1319360

Wassenaar, M. T. Groot, and R. Gradus. 2013. "Municipalities' Contracting Out Decisions: An Empirical Study on Motives." Local Government Studies 39 (3): 414-434, DOI: 10.1080/03003930.2013.778830 